\title{
The role of elementary classroom discourse in the initial construction of student identities
}

\author{
Michael A. Shepherd \\ University of Southern California \\ mshepher@usc.edu
}

\author{
Julia Wang \\ University of Southern California \\ juliadwa@usc.edu
}

\section{Introduction}

Much has been written about social identity in secondary schools and about how students use linguistic variation to mark their association with different social groups (e.g., Eckert 1989, 2000, Carter 2007, MendozaDenton 2008). There has been relatively little research, though, on the role of discourse in constructing the relevant social categories and associating students with them initially.

According to Eckert (1989), social categories such as “Jock” and "Burnout," and students' association with them, develop during primary school under the influence of such teacher-related factors as ability grouping. Putting students into different groups or classes based on their supposed ability is probably the most visible way that teachers influence students' identity development, as grouping students in this way publicly formalizes their standing in school and their relationship with it. Research on ability grouping reveals the following: that groupings are typically made quite early in an academic term-often within the first week —and are seldom changed later on (Rist 1970, Weinstein 1976); that how students are grouped is influenced by their language/dialect and their socioeconomic status (Rist 1970); that behavior (interactional style) influences grouping (Eder 1981); and, crucially, that grouping has a dramatic impact on student achievement (Schrank 1968, Weinstein 1976, Mason et al. 1992).

Eckert (1989) also discusses the role of teachers' stereotypes and expectations in students' identity development. Like all of us, teachers simplify the world by perceiving individuals in terms of categories (Stangor 2000), and teachers probably encounter many of the same types repeatedly: smart kids, shy kids, class clowns, etc. Like ability grouping, such perceptions impact student achievement by setting expectations (Jussim \& Harber 2005, Shepherd 2011). Teachers (again, like all of us) tend to set expectations they consider reasonable (van Dijk et al. 2003), because mismatch between expectations and outcomes leads to disappointment (Bell 1985). This paper explores how student categories, and the corresponding expectations, are constructed and reinforced through classroom discourse.

\section{Data and Method}

Using conversation analysis (CA), we examined the discursive construction of student identities in detailed transcripts of four third-grade reading and math lessons (students ages 8-9) by one teacher. The data come from a larger corpus of transcripts based on video-recorded classroom interactions at a diverse Southern California elementary school (for details, see Shepherd 2012). This particular teacher is White, female, and had been teaching 11 years at the time of recording. There were 20 students in her class, 10 of whom are visible on camera. We examined all interactions involving the 10 visible students.

\section{Results and Discussion}

Our findings suggest that teachers perceive two major categories of student, which we have labeled (somewhat arbitrarily) 'strong' and 'weak.' The categories relate to what teachers need to do with classroom discourse and which students they believe can help them accomplish those goals. Thus, 'strong' students tend to be those who can be relied upon to give the answers that the teacher wants said, something 'weak' students often struggle to do. Teachers' expectations of 'strong' and 'weak' students manifest themselves in the discourse and influence students’ self-perceptions. Consider excerpt (1).

\begin{tabular}{|c|c|}
\hline TEACHER & $\begin{array}{l}\text { <comprehension>. } \\
\text { Leila. } \\
\text { what's comprehension. }\end{array}$ \\
\hline LEILA & the understanding of something. \\
\hline
\end{tabular}

Participation by Leila (a 'strong' student) is framed as straightforward - the teacher expects success. Leila responds by answering immediately and with falling intonation. Contrast this with excerpt (2). 


\begin{tabular}{|l|l|}
\hline TEACHER & $\begin{array}{l}\text { I see some <unsure ha: nds>, } \\
\text { >you want to try it Quinn<, }\end{array}$ \\
\hline & $(0.6)$ \\
\hline QUINN & $<$ um> (1.2) problem? \\
\hline
\end{tabular}

Participation by Quinn (a 'weak' student) is framed as tentative, reflecting relatively lower expectations, and Quinn responds in kind, with hesitation and rising intonation, hallmarks of a dispreferred response (Levinson 1983). In other words, Quinn knows her response is likely not the one the teacher is seeking.

Such findings pose a 'chicken-or-egg' problem: Students may be responding to their teachers' confidence in them (or lack thereof), or teachers may be indexing each student's preexisting strength or weakness. It is most likely a reciprocal process, spiraling either upward or downward over time.

Excerpt (3) highlights another characteristic of interactions involving 'weak' students.

(3)

\begin{tabular}{|l|l|}
\hline TEACHER & a deep freeze. $(\odot .5)$ does anybody know what that is, \\
\hline & $(\odot .8)$ \\
\hline VALERIE & David's raising his hand. \\
\hline & $(1.3)$ \\
\hline TEACHER & $\begin{array}{l}<\text { listen>, }(\odot .3)<\text { to the sound }>. \\
(0.5)<\text { deep>, }(\odot .4)<\text { freeze } . \\
(\odot .6) \text { there's a word in there } \\
\text { that gives you a clue, }\end{array}$ \\
\hline TEACHER & $\begin{array}{l}\text { a deep? <freeze>. }(\odot .6) \\
\text { you unsure David? } \\
\text { you want to try it. }\end{array}$ \\
\hline DAVID & $\begin{array}{l}(\odot .9) \\
\text { it means like, it's like, frozen? }\end{array}$ \\
\hline
\end{tabular}

When David (a 'weak' student) raises a hand, the teacher initially holds out for other volunteers. Then, when he is finally called on, his participation is framed as tentative, and he responds in kind.

Crucially, such avoidance of 'weak' students can lead to significant frustration, as in excerpt (4).

(4)

\begin{tabular}{|c|c|}
\hline TEACHER & $\begin{array}{l}\text { who thinks they can come up, }(0.4) \text { and do } a,(0.3) \\
<\text { faster job> of <showing }>\text { the <array strategy>. ( }(0.5) \text { a } \\
\text { <faster job> showing the <array strategy>. }\end{array}$ \\
\hline TEACHER & $\begin{array}{l}\text { Zalma. come on up. } \\
\text { show [me an [array. }\end{array}$ \\
\hline DAVID & {$[\operatorname{man} !$} \\
\hline & [how can anybody $x$, \\
\hline & $(0.9)$ \\
\hline DAVID & please do sticks! \\
\hline
\end{tabular}

The "sticks" David mentions are a method of selecting students at random that this teacher sometimes uses. In other words, David knows he is being ignored but and believes he has a better chance of being selected at random. Ironically, calling out as he does is part of what marks him as a 'weak' student.

Excerpts (1) through (4) have involved teacher-initiated interactions, but differences also arise in student-initiated interactions. Students can call out, for instance, though such contributions are generally ignored unless deemed “valuable” (Mehan 1979, Lemke 1990). Crucially, comparable contributions by 'strong' students are deemed valuable more often. Students can also summon teachers, and while most are ignored (Shepherd 2012), summonses by 'strong' student are relatively more likely to be answered.

In excerpt (5), the topic is the meaning of a "deep freeze," which is a type of freezer mentioned in the reading. Chris (a 'weak' student) sees a deep freeze pictured in the book and wants to point it out. He 
summons the teacher twice but she ignores him, so he begins calling out about the picture (which, as with David, is part of what marks him as a 'weak' student).

(5) TEACHER a deep freeze--

\begin{tabular}{|c|c|}
\hline CHRIS & ${ }^{\circ}$ shows it right (there in) the picture ${ }^{\circ}$. \\
\hline TEACHER & $\begin{array}{l}\text { usually, when you see deep freezes, they're, um, they're } \\
\text { sitting, across, kind of almost like a height of the } \\
\text { table? }\end{array}$ \\
\hline CHRIS & {$[$ uh: : , } \\
\hline TEACHER & $\begin{array}{l}\text { [and the lid is at the <top>, and you lift up the lid, and } \\
\text { then you reach down, }\end{array}$ \\
\hline CHRIS & {$[$ uh: : : : , } \\
\hline TEACHER & $\begin{array}{l}\text { [into the freezer, and they call it a deep freeze, } \\
\text { [because it's deep? }\end{array}$ \\
\hline CHRIS & [well then why is it right [there. \\
\hline TEACHER & $\begin{array}{l}\text { [you can store a lot of frozen } \\
\text { [that's what a deep freeze is. }\end{array}$ \\
\hline CHRIS & [there's a deep freezer right there. \\
\hline
\end{tabular}

Thus we see Chris determinedly calling out his contribution and the teacher determinedly ignoring him.

In excerpt (6), an off-camera student has summoned the teacher, and the teacher is talking with her. Isaac (a 'strong' student) interrupts to say that he has something that he would like to talk about.

(6) TEACHER Alexis, is this something that's really important that we need to discuss right now? (0.3) or can it wait. (1.8) was it something, else about the deep freeze?

\begin{tabular}{|c|c|}
\hline & $(1.1)$ \\
\hline ISAAC & [(mine)? \\
\hline TEACHER & $\begin{array}{l}\text { [is it something really important or can it wait. because } \\
\text { we're going to, }\end{array}$ \\
\hline TEACHER & run out of time, to finish our rea[ding. \\
\hline ISAAC & needs to be done on this [page. $[<I>$, have one that \\
\hline TEACHER & {$[>$ can it wait<? } \\
\hline & $(1.1)$ \\
\hline TEACHER & ${ }^{\circ} \mathrm{okay}^{\circ}$. \\
\hline & $\begin{array}{l}\text { okay Isaac? let me finish up this page. we have one } \\
\text { sentence left on this page, and then we'll talk about it. }\end{array}$ \\
\hline
\end{tabular}

The teacher finishes the page and then gives Isaac the floor...

(7) TEACHER okay. uh:, Isaac. (0.3) you said you had something that we had to talk about, on that pa[ge.

\begin{tabular}{|r|r|}
\hline ISAAC & $\begin{array}{l}\text { [yeah, I know why they said } \\
\text { to hang on to those swings tight, because you can see the } \\
\text { swings right here, and it goes pret [ty high. }\end{array}$ \\
\hline CHRIS & \multicolumn{1}{c}{ [<yeah>. } \\
\hline TEACHER & $\begin{array}{l}\text { <oh yeah> so whe- we look at thos- you know what Isaac? } \\
\text { what you just did, ( }(0.3) \text { you used your picture, to help } \\
\text { you understand. you used your [picture to help, }\end{array}$ \\
\hline CHRIS & [that's what I did. \\
\hline
\end{tabular}




\begin{tabular}{|r|cr|}
\hline TEACHER & your comprehension, \\
\hline CHRIS & I used [it for the ice-- \\
\hline TEACHER & [and that's, $(0.4)$ & \\
\hline CHRIS & thingy. & [I used it for the ice \\
\hline TEACHER & $(0.5)<$ rice $>$ ! \\
\hline
\end{tabular}

These excerpts further highlight the very different experiences of 'strong' and 'weak' students. Chris is denied the discursive power to advance his ideas: He summons the teacher non-verbally but is ignored; he then calls out his contribution and is ignored again (and probably perceived as disruptive). Isaac interrupts but is given the floor, and his contribution is praised (and Chris recognizes the injustice).

\section{Conclusions}

Teachers allocate discursive power with particular goals in mind, and across both teacher- and studentinitiated interactions, we find that the same 'strong' students are more likely to be entrusted with this power. The 'weak' students that we studied are just as eager to contribute, but the teacher is reluctant to give them the floor. Crucially, denying 'weak' students access to discursive power can lead to significant frustration. In this third-grade classroom, the result is mildly disruptive behavior (calling out), but given people’s innate need for self-determination (Ryan \& Deci 2000), students who are denied sanctioned power are likely to seek empowerment in other ways (e.g., through resistance), ultimately developing oppositional relationships toward school. Whether this contributes to the formation of 'burnouts' is the subject of ongoing research.

\section{References}

Bell, David E. 1985. Disappointment in decision making under uncertainty. Operations Research 33(1). 1-27.

Carter, Phillip M. 2007. Phonetic variation and speaker agency: Mexicana identity in a North Carolina middle school. University of Pennsylvania Working Papers in Linguistics 13(2). 1-14.

Eckert, Penelope. 1989. Jocks and burnouts. New York, NY: Teachers College Press.

Eckert, Penelope. 2000. Linguistic variation as social practice. Malden, MA: Blackwell.

Eder, Donna. 1981. Ability grouping as a self-fulfilling prophecy: A micro-analysis of teacher-student interaction. Sociology of Education 54(3). 151-162.

Jussim, Lee \& Kent D. Harber. 2005. Teacher expectations and self-fulfilling prophecies. Personality and Social Psychology Review 9(2). 131-155.

Mason, DeWayne A., Darline D. Schroeter, Ronald K. Combs \& Karen Washington. 1992. Assigning averageachieving eighth graders to advanced mathematics classes in an urban junior high. Elementary School Journal 92(5). 587-599.

Mendoza-Denton, Norma. 2008. Homegirls. Malden, MA: Blackwell.

Rist, Ray C. 1970. Student social class and teacher expectations: The self-fulfilling prophecy in ghetto education. Harvard Educational Review 40(3). 411-451.

Ryan, Richard M. \& Edward L. Deci. 2000. Self-determination theory and the facilitation of intrinsic motivation, social development, and well-being. American Psychologist 55(1). 68-78.

Schrank, Wilburn R. 1968. The labeling effect of ability grouping. Journal of Educational Research 62. 51-52.

Shepherd, Michael A. 2011. Effects of ethnicity and gender on teachers' evaluation of students' spoken responses. Urban Education 46(5). 1011-1028.

Shepherd, Michael A. 2012. A quantitative discourse analysis of student-initiated checks of understanding during teacher-fronted lessons. Linguistics and Education 23(1). 145-159.

Stangor, Charles (ed.). 2000. Stereotypes and prejudice. Philadelphia, PA: Psychology Press.

van Dijk, Wilco W., Marcel Zeelenberg \& Joop van der Pligt. 2003. Blessed are those who expect nothing: Lowering expectations as a way of avoiding disappointment. Journal of Economic Psychology 24(4). 505-516.

Weinstein, Rhona Strasberg. 1976. Reading group membership in first grade: Teacher behaviors and pupil experience over time. Journal of Educational Psychology 68(1). 103-116. 